\title{
Assessment of Essential Metals in Selected Fish Feeds and Cultivated Fish Species in Bangladesh and their Impacts on Human Body
}

\author{
Biraj Saha $^{1 *}$, Md Abdul Mottalib ${ }^{1 *}$ and ANM Al-razee ${ }^{2}$ \\ ${ }^{1}$ Institute of Leather Engineering and Technology, University of Dhaka, Dhaka, \\ Bangladesh \\ ${ }^{2}$ Department of Analytical Chemistry and Environmental Science, Training \\ Institute for Chemical Industries, Polash, Narsingdi, Bangladesh \\ *Corresponding Author: Biraj Saha and Md Abdul Mottalib, Institute of Leather \\ Engineering and Technology, University of Dhaka, Dhaka, Bangladesh.
}

Received: September 23, 2020

Published: October 21, 2020

(C) All rights are reserved by Biraj Saha, Md

Abdul Mottalib., et al.

\begin{abstract}
Cultivated fishes are major protein and microelement sources for all sorts of people in Bangladesh due to its availability and affordability. Essential metals are persistent in the environment and are subject to bioaccumulation in the food chain. Fish is at the top of the aquatic food chain and normal metabolism of fish may accumulate large amounts of different essential metals from water, food or sediment. This study was carried out to determine essential metal concentrations in the flesh of some cultivated fish species and commercial fish feeds available in Bangladesh. The essential metal concentration in fish and consumed fish feed were assessed by Inductive Coupled Plasma Optical Emission Spectroscopy (ICP-OES) with significant variation (P < 0.05). The concentration (mg/ $\mathrm{kg}$ - dry weight) of $\mathrm{Fe}, \mathrm{Cu}, \mathrm{Zn}, \mathrm{Na}, \mathrm{K}$, and Ca were observed 23.33 - 63.3, 12.80 - 20.62, 10.00 - 26.25, 214.2 - 367.68, 285.71 - 485.71, 256.89 - 432.65 in selected commercial fish feeds whereas those were found 33.33 - 80.83, 14.00 - 31.80, 20.60 - $49.25,250.98$ $500.78,400.76$ - 587.32, 408.16 - 857.14 in cultivated fish species. All analyzed metal concentrations were within the acceptable of World Health Organization (WHO, 2004), Food and Agricultural organization (FAO, 2004), European Union (EU, 2010) and US Environmental Protection Agency (USEPA, 2011) and Total Hazardous Quotient (THQs) value of all the selected metals were lower than 1, which suggesting no remarkable non - carcinogenic health hazards for adult population.
\end{abstract}

Keywords: Essential Metal; Nutrient; Cultivated Fish; Carcinogenic; Bioaccumulation

\section{Introduction}

Fish farming is one of the most important aspects of agriculture with commercial fish contributing tremendously in meeting the upward protein demand of the increasing population through fish. Fish is a very rich and convenient source of nutrient, including microelements. The chemical composition of fish depends on both the kind and degree of the feeding animal [1]. The primary conditions for intensification of any culture depend on the natural and artificial feed. With the progress of technology and increasing demand different types of improved culture technique are now being practiced in Bangladesh. As a result, huge quantity of supple- mentary feed has to provide to the cultured species. The demand has increased 1.5 times greater than the previous five years [2]. So, the prospect of aqua feed industry is very bright in Bangladesh. It is evident that for the proper nourishment of fish a balanced diet containing energy sources - with all essential fatty acids, protein - with all essential amino acids, vitamins and minerals are very vital [3].

Fishes are one of the most important organisms in the aquatic food chain, which are very sensitive to metals contamination. Various metals are accumulated in fish body in different amounts. These differences result from different affinity of metals to fish tissues, different uptake and deposition and excretion rates. Various 
species of fish from the same water body may accumulate different amounts of metals [4,5]. Bangladesh is well known for cultivation of fish to fulfill protein demand of the country and in 2014, the country was ranked 6 th in global farmed fish production (FAO, 2016). The common sources of fish feed ingredients are maize, rice, rice polish, wheat, soybean grits, mustard oil cake, coconut oil cake, lentil bran, molasses etc. [6]. The accumulation of metals or deficiency of these elements may stimulate an alternate pathway which might produce diseases [7]. Elements such as iron, zinc are essential components of enzymes where they attract or subtract molecules and facilitate their conversion to specific end products $[8,9]$. Essential metals are required in very trace quantities for the proper functioning of enzyme systems, hemoglobin formation and vitamin synthesis in human. The body uses sodium to maintain fluid levels and it is necessary for the health of the heart, liver, and kidneys. It regulates blood fluids and prevents low blood pressure $[10,11]$. Calcium is a key nutrient in the human body. More than $99 \%$ (1.2 - $1.4 \mathrm{~kg}$ ) calcium is stored in the bones and teeth $[12,13]$. Although Copper is an important constituent in a number of different enzymes, high intakes can cause health problems such as liver and kidney damage [14]. Zinc is considered as an "essential trace element" because very small amounts of zinc are necessary for human health. It is used for boosting the immune system $[15,16]$. Although essential metal play important physiological and biochemical roles in the body as they may be part of biomolecules such as enzymes, which catalyze biochemical reactions in the body and either their deficiency or excess can lead to disturbance of metabolism and therefore causes to create various diseases $[17,18]$. As part of our ongoing research on accumulation of heavy and essential metals into food chain, we investigated the concentration of essential metals such as $\mathrm{Na}, \mathrm{K}, \mathrm{Ca}, \mathrm{Fe}, \mathrm{Cu}$ and $\mathrm{Zn}$ in selected renowned fish feeds and cultivated fish tissues collected from Khulna District, the southern part of Bangladesh.

\section{Aim of the Study}

This study is also aimed at evaluating the risk of metals in fishes. The obtained results have been reported in this article.

\section{Materials and Methods}

Sample collection

Seven types of Fish and their respective commercial feeds were collected from the fish cultivating firm in the southern part of Bangladesh. The analyzed fishes were cultivated for 8 to 10 months in individual cultivating firm. Fish samples were collected by considering the selected fish feed, age, length, weight of the fishes.

\section{Digestion and analysis}

All collected fish samples were cut into small species and dried them in an oven at $105^{\circ} \mathrm{C}$ until a constant weight was achieved and finally powdered. Feed samples also were dried in similar way. $1 \mathrm{~g}$ of the homogenate of each sample (dry weight) was taken into a quick fit round bottom flask and $15 \mathrm{~mL}$ mixture of concentrated $\mathrm{HNO}_{3}, \mathrm{H}_{2} \mathrm{SO}_{4}$ and $\mathrm{HClO}_{4}$ in $(4: 1: 1 ; \mathrm{v} / \mathrm{v})$ was added into the flask. A condenser was set up with the flask and the mixture was stirred at $85^{\circ} \mathrm{C}$ for 3 hours until the proper digestion was completed and the solution became clear [19]. Filtration of all digested samples was done with Whitman no. 42 filter paper and the filtrated was transferred into the volumetric flask and finally diluted to $50 \mathrm{~mL}$ with deionize water. Samples were stored at ambient temperature until metal analysis. All chemicals used were Merck, Germany analytical grade, including standard stock solutions of known concentrations of different metals. The entire samples were analyzed by Inductive Coupled Plasma-Optical Emission Spectroscopy (ICP-OES) with detection limit (mg/kg) for $\mathrm{Na}$ (0.001), K (0.010), Ca (0.001), Fe (0.010), Cu (0.001), Zn (0.001). Blank samples were analyzed after seven samples. All analyses were replicated three times. The precision and analytical accuracy of the analyses were checked by the analysis of standard reference material C.P.A Chem., Bulgaria.

\section{Health risk estimation}

The target hazard quotient (THQ) is the estimate of the risk level (non-carcinogenic) due to pollutant exposure. To estimate the human health risk from consuming metal - contaminated fish, the target hazard quotient (THQ) was calculated as per USEPA using following formula [20]:

$$
T H Q=\frac{E D \times E F \times F I R \times C F \times C M}{W A B \times A T n \times R f D} \times 10^{-3}
$$

Hazard Index $(\mathrm{HI})=\mathrm{THQ}_{\mathrm{Fe}}+\mathrm{THQ}_{\mathrm{Cu}}+\mathrm{THQ}_{\mathrm{Zn}}$

Where THQ is the target hazard quotient, EF is the exposure frequency (365 days/year), ED is the exposure duration (70 years for Bangladeshi population [21]), FIR is the fish ingestion rate (49.5 g/ person/day), $\mathrm{CF}$ is the conversion factor (0.208) to convert fresh weight (Fw) to dry weight (Dw) considering $79 \%$ of moisture content in fish, $\mathrm{CM}$ is the heavy metal concentration in fish $(\mathrm{mg} / \mathrm{kg}$, dry weight), WAB is the average body weight (bw) (70 Kg) [21], ATn is the average exposure time for non-carcinogens (EF×ED) (365 days/year for 70 years (i.e. ATn $=25,550$ days) as used in characterizing non-cancer risk and RfD is the reference dose of the metal 
an estimate of the daily exposure to which the human population may be continuously exposed over a lifetime without an appreciable risk of deleterious effects [22].

\section{Statistical analysis}

All statistical analyses were performed using the Microsoft Excel (version 2016). Analysis of variance (Two-way ANOVA) and correlation matrix were employed to examine statistical significance of differences in the mean concentration of metals between (or among) group of families of fish feed and fish. A probability level of $\mathrm{P}<0.05$ was considered statistically significant.

\section{Results and Discussion}

Table 1 represents seven brands of commercial fish feed those were provided to 7 types of cultivated fish for a certain period in individual cultivating firm including age, length and weight of fishes.

The summary of the concentrations of essential metals such as $\mathrm{Fe}, \mathrm{Cu}, \mathrm{Zn}, \mathrm{Na}, \mathrm{K}$ and $\mathrm{Ca}$ found in different commercial fish feed is presented in table 2 . The highest concentration of Fe $(63.33 \mathrm{mg} /$ $\mathrm{kg}$ ) was found in ACI fish feed and the lowest concentration was $23.33 \mathrm{mg} / \mathrm{kg}$ in Teer fish feed. The average concentration of Fe in analyzed feed samples found $41.84 \mathrm{mg} / \mathrm{kg}$ which was within the acceptable limit according to WHO and USEPA $[20,23]$.

\begin{tabular}{|l|c|c|c|c|c|c|}
\hline No. & Feed Sample & $\begin{array}{c}\text { Names of cultivated fish } \\
\text { (Scientific Name) }\end{array}$ & $\begin{array}{c}\text { Cultivated fish } \\
\text { (Local Name) }\end{array}$ & $\begin{array}{c}\text { Age } \\
\text { (Month) }\end{array}$ & $\begin{array}{c}\text { Length } \\
\text { (cm) }\end{array}$ & $\begin{array}{c}\text { Weight } \\
\text { (gm) }\end{array}$ \\
\hline 01 & FF1 & Labeo rohita & Rui Fish & 8 & 58.42 & 2300 \\
\hline 02 & FF2 & Hypophthalmichthys molitrix & Silver Carp & 8 & 55.88 & 2000 \\
\hline 03 & FF3 & Puntius sarana & Sarpunti & 5 & 26.67 & 350 \\
\hline 04 & FF4 & Labeo calbasu & Kaalibaus & 7 & 43.18 & 1500 \\
\hline 05 & FF5 & Anabas testudineus & Koi & 4 & 19.05 & 200 \\
\hline 06 & FF6 & Ctenopharyngodon idella & Grass Carp & 8 & 60.96 & 2500 \\
\hline 07 & FF7 & Oreochromis niloticus & Tilapia & 8 & 33.02 & 1100 \\
\hline
\end{tabular}

Table 1: Different types of cultivated fish and their commercial fish feeds.

\begin{tabular}{|c|c|c|c|c|c|c|c|c|c|}
\hline No. & Sample & \multicolumn{2}{|c|}{ Brand of fish feed } & $\mathbf{F e}$ & $\mathbf{C u}$ & Zn & $\mathrm{Na}$ & $\mathbf{K}$ & $\mathrm{Ca}$ \\
\hline 01 & FF1 & \multicolumn{2}{|c|}{ Fresh Fish Feed } & 49.56 & 14.74 & 12.13 & 367.68 & 285.71 & 273.56 \\
\hline 02 & FF2 & \multicolumn{2}{|c|}{ Teer Fish Feed } & 23.33 & 11.23 & 10.00 & 367.57 & 412.86 & 323.78 \\
\hline 03 & FF3 & \multicolumn{2}{|c|}{ ACI Fish Feed } & 63.33 & 20.62 & 25.00 & 308.38 & 285.71 & 389.56 \\
\hline 04 & FF4 & \multicolumn{2}{|c|}{ Quality Fish Feed } & 51.33 & 20.21 & 25.00 & 335.14 & 428.57 & 256.89 \\
\hline 05 & FF5 & \multicolumn{2}{|c|}{ Saudi Bangla Feed } & 36.67 & 12.80 & 26.25 & 254.54 & 485.71 & 375.54 \\
\hline 06 & FF6 & \multicolumn{2}{|c|}{ Mega Fish Feed } & 28.00 & 18.68 & 15.63 & 304.32 & 328.57 & 573.49 \\
\hline 07 & FF7 & \multicolumn{2}{|c|}{ Mesh Fish Feed } & 40.67 & 17.29 & 25.63 & 214.32 & 357.14 & 432.65 \\
\hline \multicolumn{4}{|c|}{ Mean } & 41.84 & 16.51 & 19.95 & 307.41 & 369.18 & 375.07 \\
\hline \multirow{3}{*}{\multicolumn{3}{|c|}{ Standard Limit (mg/kg) }} & $\begin{array}{c}\mathrm{FAO} / \mathrm{WHO} \\
{[23]}\end{array}$ & 100 & 30 & 40 & 700 & 900 & 900 \\
\hline & & & EU [24] & $\cdots$ & 30 & 40 & 700 & $500-1000$ & -- \\
\hline & & & USEPA [20] & $90-100$ & $\cdots$. & $\cdots$. & $\cdots$ & $\cdots$ & 1000 \\
\hline
\end{tabular}

Table 2: Concentration of essential metals (mg/kg, dry weight) in the brands of commercial fish feed. 
From the result of elemental concentration, $\mathrm{Cu}$ ranged from 11.23 to $20.62 \mathrm{mg} / \mathrm{kg}$. The maximum concentration of $\mathrm{Cu}(20.62$ $\mathrm{mg} / \mathrm{kg}$ ) was found in ACI fish feed and the lowest content $(11.23$ $\mathrm{mg} / \mathrm{kg}$ ) was in Teer fish feed. The mean concentration of $\mathrm{Cu}(16.51$ $\mathrm{mg} / \mathrm{kg}$ ) which was lower than the maximum permissible limits 30 $\mathrm{mg} / \mathrm{kg}$ according to EU [24] and also lower than 22.618 to 38.480 $\mathrm{mg} / \mathrm{kg}$ which was found in previous study [1]. The Zn content in these feeds was ranged from $10.00-26.25 \mathrm{mg} / \mathrm{kg}$ which is acceptable by FAO and USEPA $[23,24]$. In current study, the Na content ranged from $214.32-367.68 \mathrm{mg} / \mathrm{kg}$ which was lower than the results $891.04-1079.13 \mathrm{mg} / \mathrm{kg}$ found in previous study [1]. The average concentration of $\mathrm{Na}(307.41 \mathrm{mg} / \mathrm{kg})$ found in the current study was within the acceptable limit by WHO and EU [23,24]. The highest concentration of $\mathrm{K}(485.71 \mathrm{mg} / \mathrm{kg})$ was found in Saudi Bangla feed whereas lowest $(285.71 \mathrm{mg} / \mathrm{kg}$ ) in Fresh and ACI fish feed. The average concentration of $\mathrm{K}(369.18 \mathrm{mg} / \mathrm{kg})$ was below the permissible limit $(900 \mathrm{mg} / \mathrm{kg}$ ) by WHO [23]. Calcium content was recorded in this study from $256.89 \mathrm{mg} / \mathrm{kg}$ to $573.49 \mathrm{mg} / \mathrm{kg}$. The highest concentration of Ca found in Mega Fish Feed while the lowest content was recorded in Quality Fish Feed. The mean value of Ca (375.07 mg/kg) was within acceptable limit by EU [24].

Table 3 summarizes the concentration of elements determined for fish samples. The seven fish samples were analyzed. The values of elemental concentration for Fe ranged from 33.33 to $80.83 \mathrm{mg} /$ $\mathrm{kg}$, Cu ranged from 14.00 to $31.80 \mathrm{mg} / \mathrm{kg}$, Zn ranged from 20.60 to $49.25 \mathrm{mg} / \mathrm{kg}$, Na ranged from 250.98 to $500.78 \mathrm{mg} / \mathrm{kg}$, K ranged from 400.76 to $587.32 \mathrm{mg} / \mathrm{kg}$ and Ca ranged from 408.16 to 857.14 $\mathrm{mg} / \mathrm{kg}$. The highest Fe content was found in Puntius sarana while lowest was found in Hypophthalmichthys molitrix fish. The mean value for Fe was $52.86 \mathrm{mg} / \mathrm{kg}$, which was lower than $185 \mathrm{mg} / \mathrm{kg}$ recorded in a previous study [26]. The obtained range of Fe in this study was within the acceptable limits according to WHO and EU $[24,25]$. The mean value of $\mathrm{Cu}$ and $\mathrm{Zn}$ was found $23.32 \mathrm{mg} / \mathrm{kg}$ and $32.11 \mathrm{~m} / \mathrm{kg}$, which were also lower than $31.15 \mathrm{mg} / \mathrm{kg}$ and 52.87 $\mathrm{mg} / \mathrm{kg}$ respectably recorded in a previous study [26]. The highest concentration of Cu was found in Puntius sarana and that was lowest in Anabas testudineus. The experimented result for $\mathrm{Cu}$ and $\mathrm{Zn}$ was not exceeded the permissible limit of WHO and EU [24,25]. The recorded mean value of $\mathrm{Na}$ and $\mathrm{K}$ was $377.09 \mathrm{mg} / \mathrm{kg}$ and 523.16 $\mathrm{mg} / \mathrm{kg}$ which also acceptable by WHO and EU $[23,25]$. A previous study found mean value of $\mathrm{Na}$ and $\mathrm{K}$ was $900 \mathrm{mg} / \mathrm{kg}$ and $700 \mathrm{mg} /$ $\mathrm{kg}$ respectably, which were higher than the current study [27]. The highest concentration of $\mathrm{Ca}(857.14 \mathrm{mg} / \mathrm{kg})$ found in Hypophthalmichthys molitrix fish and the lowest concentration was 408.16 $\mathrm{mg} / \mathrm{kg}$ in Labeo calbasu fish. The average value of Ca was 596.92 $\mathrm{mg} / \mathrm{kg}$ which is also within the permissible limit set by FAO and EU $[24,25]$.

\begin{tabular}{|c|c|c|c|c|c|c|c|c|}
\hline No. & Sample & Scientific name of fish & $\mathbf{F e}$ & $\mathrm{Cu}$ & Zn & $\mathrm{Na}$ & $\mathbf{K}$ & $\mathrm{Ca}$ \\
\hline 01 & F1 & Labeo rohita & 62.50 & 20.00 & 23.88 & 400.78 & 567.43 & 518.37 \\
\hline 02 & $\mathrm{~F} 2$ & $\begin{array}{c}\text { Hypophthalmichthys } \\
\text { molitrix }\end{array}$ & 30.00 & 24.67 & 25.82 & 500.78 & 587.32 & 857.14 \\
\hline 03 & F3 & Puntius sarana & 80.83 & 31.80 & 28.36 & 378.76 & 400.76 & 634.69 \\
\hline 04 & $\mathrm{~F} 4$ & Labeo calbasu & 55.00 & 22.50 & 49.25 & 456.98 & 576.58 & 408.16 \\
\hline 05 & F5 & Anabas testudineus & 41.67 & 14.00 & 44.78 & 300.65 & 543.78 & 497.96 \\
\hline 06 & F6 & Ctenopharyngodon idella & 33.33 & 21.70 & 20.60 & 350.76 & 498.67 & 676.41 \\
\hline 07 & F7 & Oreochromis niloticus & 66.67 & 28.60 & 32.09 & 250.98 & 487.56 & 585.71 \\
\hline \multicolumn{3}{|r|}{ Mean } & 52.86 & 23.32 & 32.11 & 377.09 & 523.16 & 596.92 \\
\hline \multicolumn{3}{|c|}{ Standard Deviation } & 17.32 & 5.38 & 10.06 & 79.89 & 61.18 & 134.79 \\
\hline \multirow{2}{*}{\multicolumn{2}{|c|}{$\begin{array}{l}\text { Standard Limit } \\
(\mathrm{mg} / \mathrm{kg})\end{array}$}} & FAO/WHO $[23,25]$ & 100 & 30 & 40 & 700 & 900 & 900 \\
\hline & & EU [24] & 100 & 30 & 40 & 700 & 1000 & 1000 \\
\hline
\end{tabular}

Table 3: Concentration of essential metals ( $\mathrm{mg} / \mathrm{kg}$, dry weight) in cultivated fish samples.

Translocation of selected metals from fish feeds into cultivated fishes in current study found that the concentration of essential metals in fish samples were more than their respective commercial fish feed (Figure 1). The mean concentration of Fe in fish samples was $25 \%$ more than their consumed fish feeds. In case of $\mathrm{Cu}$ and
$\mathrm{Zn}$, the increasing rate from feed to fish was $41 \%$ and $60 \%$ respectively whereas other essential metals $\mathrm{Na}, \mathrm{K}$ and $\mathrm{Ca}$ was also increased in fish species by $27 \%, 36 \%$ and $57 \%$ respectably (Figure 1). However, though the concentration rate of selected metals was noticeably high from feed to fish but their final content in selected fishes was within permissible limit. 


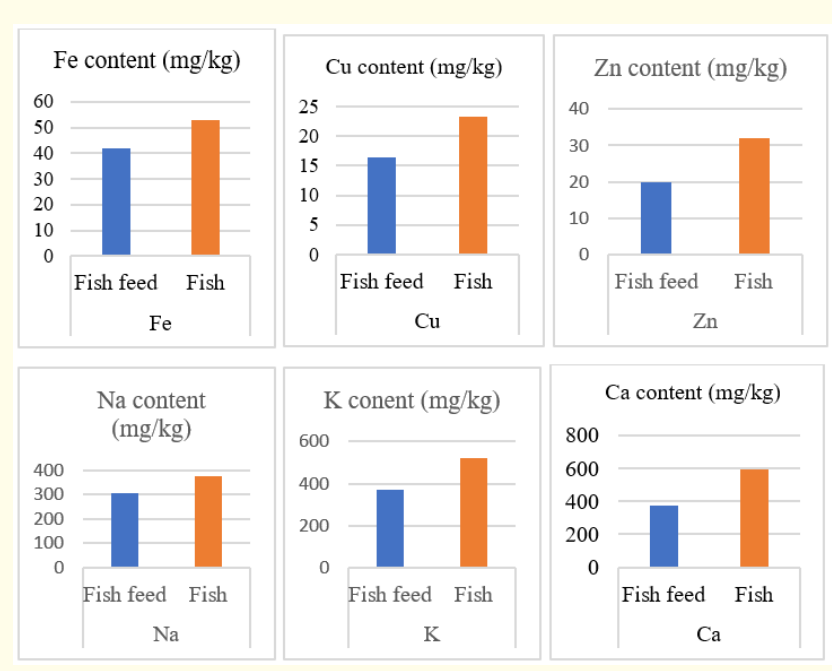

Figure 1: Metal content in fish feed and in cultivated fishes.

Target Hazard Quotient (THQ) of three essential metals such as $\mathrm{Fe}, \mathrm{Cu}$ and $\mathrm{Zn}$ were calculated according to the reported equation [20] and their values are represented in table 4.

\begin{tabular}{|c|c|c|c|c|c|c|c|c|}
\hline & \multicolumn{6}{|c|}{ Target Hazard Quotient (THQ) } \\
\hline $\begin{array}{c}\text { Met- } \\
\text { al }\end{array}$ & $\begin{array}{c}\text { RfD } \\
\text { (mg/kg) }\end{array}$ & F1 & F2 & F3 & F4 & F5 & F6 & F7 \\
\hline Fe & 0.7 & 0.02 & 0.01 & 0.03 & 0.02 & 0.01 & 0.01 & 0.02 \\
\hline $\mathrm{Cu}$ & 0.04 & 0.07 & 0.09 & 0.10 & 0.08 & 0.05 & 0.07 & 0.10 \\
\hline $\mathrm{Zn}$ & 0.3 & 0.01 & 0.01 & 0.02 & 0.05 & 0.04 & 0.01 & 0.03 \\
\hline \multicolumn{2}{|c|}{ Total THQ or HI } & 0.10 & 0.11 & 0.15 & 0.15 & 0.10 & 0.09 & 0.15 \\
\hline
\end{tabular}

Table 4: THQ value of $\mathrm{Fe}, \mathrm{Cu}$ and $\mathrm{Zn}$ in fish samples.

Table 4 shows total THQ or HI value for individual metal was lower than 1.0, USEPA standard [20] in individual fish species for all selected metals which expressed that no non-carcinogenic risks found for human health due to the consumption of those metals.

The Perason Correlation Coefficient in the present study is used to describe the inter relationships between the elements analyzed at a level of $>0.5$ or $<-0.5$ which are significantly correlated [28]. Table 5 shows a high possitive correlation between $\mathrm{Fe}-\mathrm{Cu}(0.60)$ and $\mathrm{Na}-\mathrm{K}(0.70)$ which indicates the simillar source of these metals in fish samples. By two way factor Anova analysis (MS office 2016), the present study found that F-critical values were higher than $\mathrm{F}$ values on contray, $\mathrm{P}$ values were greater than $\alpha$ value $(0.05)$ in each individual fish species. Thus, there was a significant $(\mathrm{P}>$ 0.05) difference for all metal concentration in each individual fish species. In contrast, $\mathrm{F}$ value was higher than F-critical value as a result $P$ value is less than $\alpha$ value (0.05). Thus, There was no significant differences at $\mathrm{P}<0.05$ for individual metal in all the selected fish species [28].

\begin{tabular}{|c|c|c|c|c|c|c|}
\hline & $\mathrm{Fe}$ & $\mathrm{Cu}$ & $\mathrm{Zn}$ & $\mathrm{Na}$ & $\mathrm{K}$ & $\mathrm{Ca}$ \\
\hline $\mathrm{Fe}$ & 1 & & & & & \\
\hline $\mathrm{Cu}$ & $0.6^{*}$ & 1 & & & & \\
\hline $\mathrm{Zn}$ & 0.07 & -0.63 & 1 & & & \\
\hline $\mathrm{Na}$ & -0.28 & 0.04 & -0.05 & 1 & & \\
\hline $\mathrm{K}$ & -0.62 & -0.64 & 0.3 & $0.7^{*}$ & 1 & \\
\hline $\mathrm{Ca}$ & -0.41 & 0.4 & -0.7 & 0.3 & -0.09 & 1 \\
\hline
\end{tabular}

Table 5: Correlation matrix of selected metals in cultivated fishes.

\section{Conclusion}

Essential metals are very important for body growth that adult can get through daily fish consumption worldwide. This study revealed that the concentration of selected essential metals in commercial fish feeds and cultivated fish samples were within the acceptable limits compared to standard value of WHO/FAO, EU, USEPA. Metal concentration in fish samples were higher than their respective commercial fish feed samples which can be happened due to metabolism rate in fishes. This study found that there are no significant differences $(\mathrm{P}<0.05)$ for individual metal content in all fish samples. The THQ values of analyzed essential metals was less than 1 which indicated that these fish samples had no non carcinogenic impact on human body. So, people can meet the essential metal demand by consuming these fishes for a long time.

\section{Bibliography}

1. GK Kundu., et al. "Metal contamination of commercial fish feed and quality aspects of farmed tilapia (Oreochromis niloticus) in Bangladesh". Bioresearch Communications 3.1 (2017): 465474.

2. MI Hossain., et al. "Bioaccumulation of heavy metals in tilapia fed with commercial fish feeds". Bangladesh Journal of Scientific Research 29.2 (2016): 89-99.

3. A Bahar., et al. "Metals major, essential to non-essential composition of the different tissues of three demersal fish species from İskenderun Bay, Turkey". Food Chemistry 123.2 (2015): 410-415.

4. P Kotze., et al. "Bioaccumulation of copper and zinc in Oreochromis mossambicus and Clarias gariepinus, from the Olifants River, Mpumalanga, South Africa". Water SA 25.1 (1999): 99110. 
5. SE Abalaka., et al. "Heavy Metals Bioaccumulation and Health Risks with Associated Histopathological Changes in Clarias gariepinus from the Kado Fish Market, Abuja, Nigeria". The Journal of Health and Pollution 7.13 (2017): 66-72.

6. B Saha., et al. "Assessment of selected heavy metals concentration in different brands of fish feed available in Bangladesh". Journal of Bangladesh Academy of Sciences 42.2 (2018): 207210.

7. JH Duffus. "Heavy metals-a meaningless term?" Pure and Applied Chemistry 74.5 (2002): 793-807.

8. O Wada. "Their deficiency and excess states". Japan Medical Association Journal 47 (2004): 351-358.

9. MA Mottalib., et al. "Assessment of trace metals in consumer chickens in Bangladesh". The Journal of Health and Pollution 8.20 (2018): 1-10.

10. M Constantin and I Alexandru. "The role of sodium in the body". Balneo- Research Journal 2 (2011): 71-74.

11. M Nishimuta., et al. "Dietary Salt (Sodium Chloride) Requirement and Adverse Effects of Salt Restriction in Humans". Journal of Nutritional Science and Vitaminology 64.2 (2018): 8389.

12. YS Choi., et al. "Evidence for revising calcium dietary reference intakes (DRIs) for Korean elderly". The FASEB Journal 27 (2013):1065.

13. RY Velde., et al. "Calcium and vitamin D supplementation: state of the art for daily practice". Food and Nutrition Research (2014): 34-54.

14. Agency for Toxic Substances and Disease Registry, Division of Toxicology". Toxicological Profile for Chroium (2004).

15. SA Abduljalil and MA Othaman. "Metals concentration in eggs of domestic avian and estimation of health risk from eggs consumption". Biological sciences 11.7 (2011): 448-453.

16. NG Sathawara., et al. "Essential heavy metals in environmental samples from western India”. Environmental Contamination and Toxicology 73 (2004): 264-269.

17. H Ali and E Khan. "Environmental Chemistry and Ecotoxicology of Hazardous Heavy Metals: Environmental Persistence, Toxicity, and Bioaccumulation". Journal of Chemistry (2019): $1-14$.

18. AK Ahmed., et al. "Human health risks from heavy metals in fish of Buriganga river, Bangladesh". Springer Plus 5 (2016): 1-12.
19. SE Allen., et al. "Chemical Analysis". In: Moore PD, Chapman SB (editions) Methods in Plant ecology". Blackwell Scientific Publication, Oxford (1986): 285-344.

20. USEPA. Regional Screening Levels (RSLs) - Generic Tables (2011).

21. M Uddin., et al. "Status of elderly people of Bangladesh: health perspective". Proceeding of Pakistan Academy of Sciences 47.3 (2010): 181-189.

22. MA Mannan., et al. "Bioaccumulation of Toxic Heavy Metals in Fish after Feeding with Synthetic Feed: A Potential Health Risk in Bangladesh". Journal of Nutrition and Food Sciences 8.5 (2018): 1-7.

23. World Health Organization (WHO) and Food and Agricultural Organization (FAO). Guidelines for assessing the nutritional impact of supplementary feeding programs (2004).

24. European Union (EU), Feed Standard Agency, Feed and Food control regulation (2010).

25. FAO. Fisheries and Aquaculture topics. The state of world fisheries and aquaculture. Topics Fact Sheet. In: FAO Fisheries and aquaculture department (2016).

26. H Alipour., et al. "Determination of metals (As, $\mathrm{Cu}, \mathrm{Fe}$, and $\mathrm{Zn}$ ) in two fish species from the Miankaleh wetland". Archives of Polish Fisheries 23 (2016): 99-105.

27. Z Umer., et al. "Assessment of heavy metal contaminants from protein sources". Journal of Food Technology and Preservation 1.2 (2017): 7-11.

28. MS Ahmed., et al. "Translocation of heavy metals from industry into vegetables and crops through water and soil of Mokesh Beel in Bangladesh and their Impact on Human Body". IOSR Journal of Environmental Science, Toxicology and Food Technology 13 (2019): 59-67.

\section{Assets from publication with us}

- Prompt Acknowledgement after receiving the article

- Thorough Double blinded peer review

- Rapid Publication

- Issue of Publication Certificate

- High visibility of your Published work

Website: www.actascientific.com/

Submit Article: www.actascientific.com/submission.php

Email us: editor@actascientific.com

Contact us: +919182824667 